報 文

\title{
LC-MS/MSによる畜水産物中のフルオピコリド分析法
}

(平成 28 年 3 月 25 日受理)

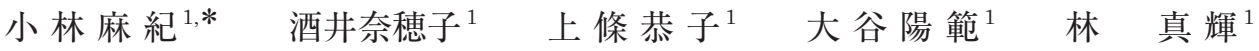

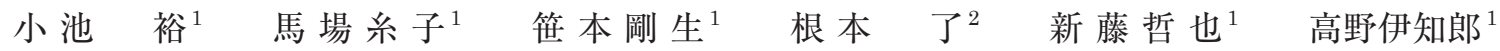

\section{Determination of Fluopicolide in Livestock Products and Seafood by LC-MS/MS}

Maki KobaYashi ${ }^{1, *}$, Naoko SAkai ${ }^{1}$, Kyoko Kamijo ${ }^{1}$, Harunori Otani ${ }^{1}$, Masaki HaYashi ${ }^{1}$, Hiroshi Koike ${ }^{1}$, Itoko Baba ${ }^{1}$, Takeo SASAmoto ${ }^{1}$, Satoru Nemoto ${ }^{2}$, Tetsuya Shindo $^{1}$ and Ichiro Takano ${ }^{1}$

${ }^{1}$ Tokyo Metropolitan Institute of Public Health: 3-24-1 Hyakunin-cho, Shinjuku-ku, Tokyo 169-0073, Japan;

${ }^{2}$ National Institute of Health Sciences: 1-18-1 Kamiyoga, Setagaya-ku, Tokyo 158-8501, Japan;

${ }^{*}$ Corresponding author

An analytical method for the determination of fluopicolide in livestock products and seafood was developed using LC-MS/MS. Sodium chloride was added to livestock products and seafood samples and fluopicolide was extracted twice with acetone after acidification with formic acid. The fat from the crude extract was removed using a macroporous diatomaceous earth column, followed by purification with a combination of mini-columns of GC (graphite carbon) and PSA (ethylenediamine- $N$-propyl silylation silica gel). The average recovery $(n=5)$ of fluopicolide from 10 types of livestock products and seafood (cattle fat, cattle liver, cattle muscle, chicken, eel, egg, freshwater clam, honey, milk and salmon) spiked at the MRLs or at the uniform limit (0.01 ppm) was 96$100 \%$, with a relative standard deviation of $2.3-6.2 \%$. The limit of quantitation of the developed method was calculated to be $0.01 \mathrm{mg} / \mathrm{kg}$.

(Received March 25, 2016)

Key words: フルオピコリドfluopicolide; 畜産物 livestock products; 水産物 seafood; 液体クロマトグ ラフータンデム型質量分析計 LC-MS/MS

緒言

フルオピコリド（Fig. 1）は，1998年にドイツのアグレ ボ社（現バイエルクロップサイエンス社）により開発さ れ, 薬剤耐性菌にも効果を発揮する新規農業用殺菌剂であ る.フルオピコリドは, 卵菌網 (Oomycetes) に属するト マト，ミニトマト，はくさい，たまねぎおよびきゅうりな どの各種作物のべと病および疫病に対して実用性を有す る. 作用機構は解明に至っていないが, 電子伝達系阻害, 脱共役阻害, セルロース生合性阻害など以外の作用機構を 有する可能性が示唆されている*1,1).

フルオピコリドは, わが国において 2008 年に農薬登録さ

* 連絡先 Maki_Kobayashi@member.metro.tokyo.jp

1 東京都健康安全研究センター： ₹169-0073 東京都新宿区 百人町 3-24-1

2 国立医薬品食品衛生研究所： $=158-8501$ 東京都世田谷区 上用賀 1-18-1

*1 独立行政法人農林水産消費安全技術センター (FAMIC), 農 薬抄録掞よび評価書, 農薬抄録一般名フルオピコリド（殺菌 剂), http://www.acis.famic.go.jp/syouroku/fluopicolide/index. $\mathrm{htm}, 2012$ 年 9 月 25 日掲載

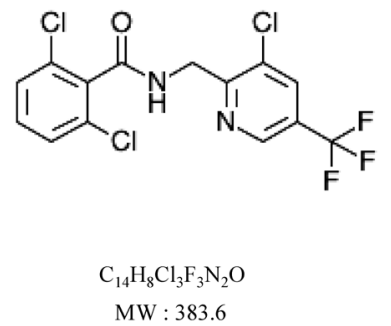

Fig. 1. Structure of fluopicolide

れ，食品衛生法の規格基準がばれいしょなどの農産物に 0.02 25 ppmおよび牛の筋肉などの畜水産物に $0.01 〜$ $0.02 \mathrm{ppm}$ が設定されている．基準值の設定されていない食 品については一律基準值 $0.01 \mathrm{ppm}$ が適用される。農産物 については, 一斉試験法および個別試験法の報告があ $り^{2), 3)}$, また, 厚生労働省から個別試験法として「フルオピ コリド試験法（農産物）」*2,4) が通知されているが，畜水産

*2 厚生労働省医薬食品局食品安全部長通知：食品に残留する農 薬，飼料添加物または動物用医薬品の成分である物質の試験 法について, 平成 17 年 1 月 24 日, 食安発第 0124001 号. 
物を対象として検討した試験法の報告はほとんどない.

そこで, 畜水産物を対象とした高感度で選択性の高い LC-MS/MSによる試験法を開発し, 畜水産物への適用性 について検討したので報告する.

\section{実験方法}

\section{1. 試料}

東京都内で市販されていた牛の筋肉, 鶏の筋肉, 牛の脂 肪, 牛の肝臓, 鶏卵, 牛乳, はちみつ (そば蜜), うなぎ, さけおよびしじみの計 10 種を用いた。

牛の筋肉, 鶏の筋肉, 牛の脂肪および牛の肝臓は, 細切 したのちフードプロセッサーを用いて均一化した。牛乳は そのまま, 鶏卵は殼を除去後, はちみつは $30^{\circ} \mathrm{C}$ に加温後, フードプロセッサーを用いてかくはん均一化した．うなぎ およびさけは可食部を細切した後, しじみは殼を除去後, フードプロセッサーを用いて均一化した。

\section{2. 試 薬}

フルオピコリド標準品はシグマアルドリッチ製（純度 99.9％）の残留農薬試験用農薬標準品を用いた。この $20.0 \mathrm{mg}$ を量り採り, アセトニトリルに溶解し, 正確に $20 \mathrm{~mL}$ とて標準原液とした。標準原液を用事, アセトニ トリルで適宜希釈し，測定用標準溶液とした。また，標準 原液をアセトンで希釈し, 添加回収用標準溶液とした。
塩化ナトリウム，アセトンおよびアセトニトリルは和光 純薬工業(株)製の残留農薬試験用を，ギ酸，酢酸アンモニ ウム溶液および移動相のアセトニトリルは和光純薬工業 (株)製のLC-MS用を用いた。

水はMilli- $\mathrm{Q}^{\circledR}$ 超純水装置（(株) 日本ミリポア社製）によ り精製して用いた.

多孔性ケイソウ土カラムはジーエルサイエンス社製 InertSep K-solute（10 mL保持用）を用いた.

精製用固相ミニカラムは，ジーエルサイエンス社製の InertSep GC (グラファイトカーボン) $250 \mathrm{mg} / 3 \mathrm{~mL}$ およ びInertSep PSA（エチレンジアミン- $N$-プロピルシリル化 シリカゲル） $500 \mathrm{mg} / 3 \mathrm{~mL}$ 用いた。

\section{3. 装置}

ホモジナイザーはマイクロテック・ニチオン社製ヒスコ トロン NS-52, 遠心分離機はトミー精工社製AX-321, 減 圧濃縮装置はBuchi 社製R-215を用いた，高速液体クロマ トグラフはWaters社製ACQUITY UPLC，質量分析装置 はWaters社製 Quattro Premier XEを用いた。

\section{4. 測定条件}

LC-MS/MS 条件はTable 1 に示した。

\section{5. 試験溶液の調製}

試料 $10 \mathrm{~g}$ に塩化ナトリウム $1 \mathrm{~g}$ および $1 \mathrm{vol} \%$ ギ酸 $10 \mathrm{~mL}$ 加えた。 そこへアセトン $50 \mathrm{~mL}$ を加え，ホモジ

Table 1. LC-MS/MS operating conditions

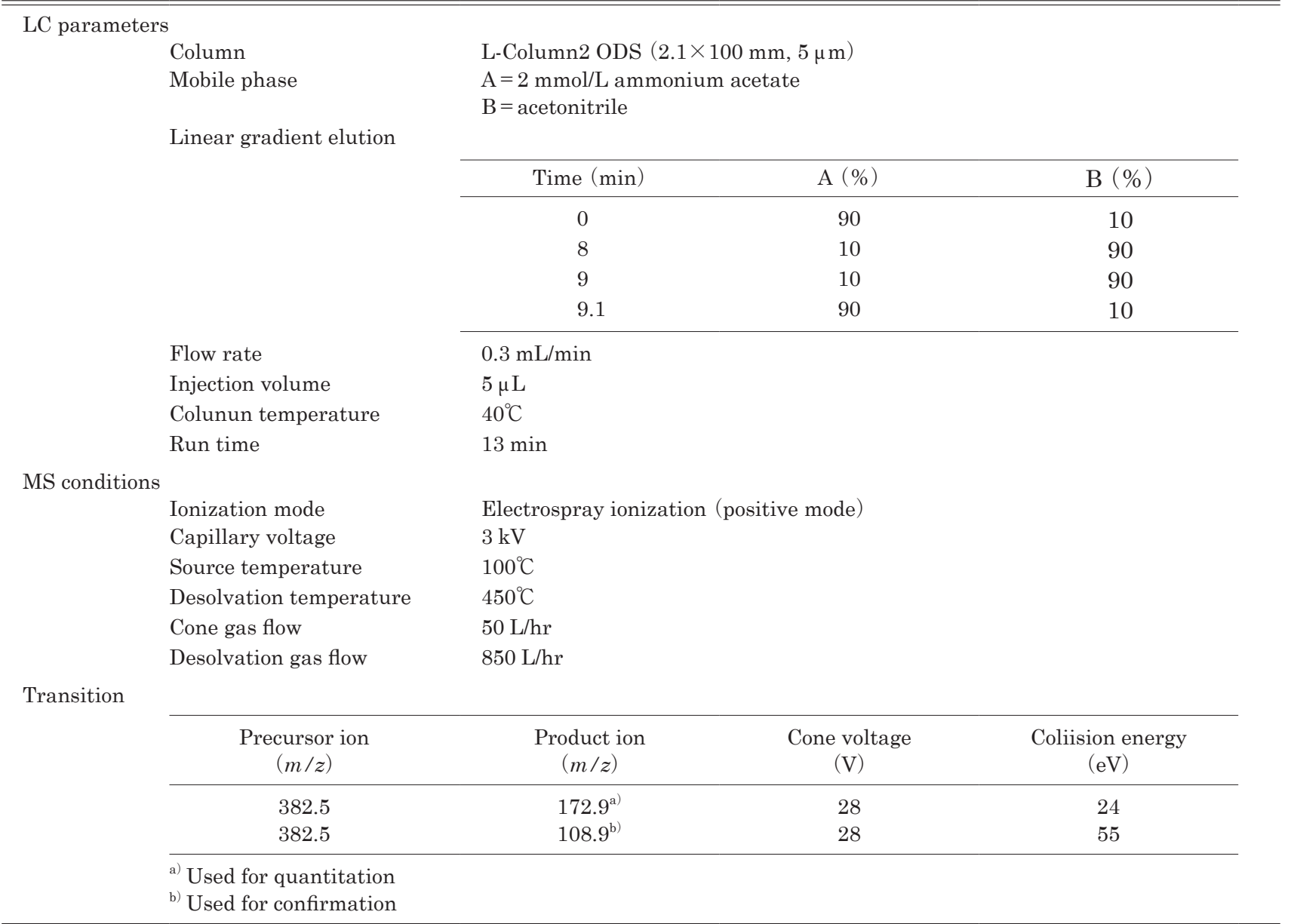




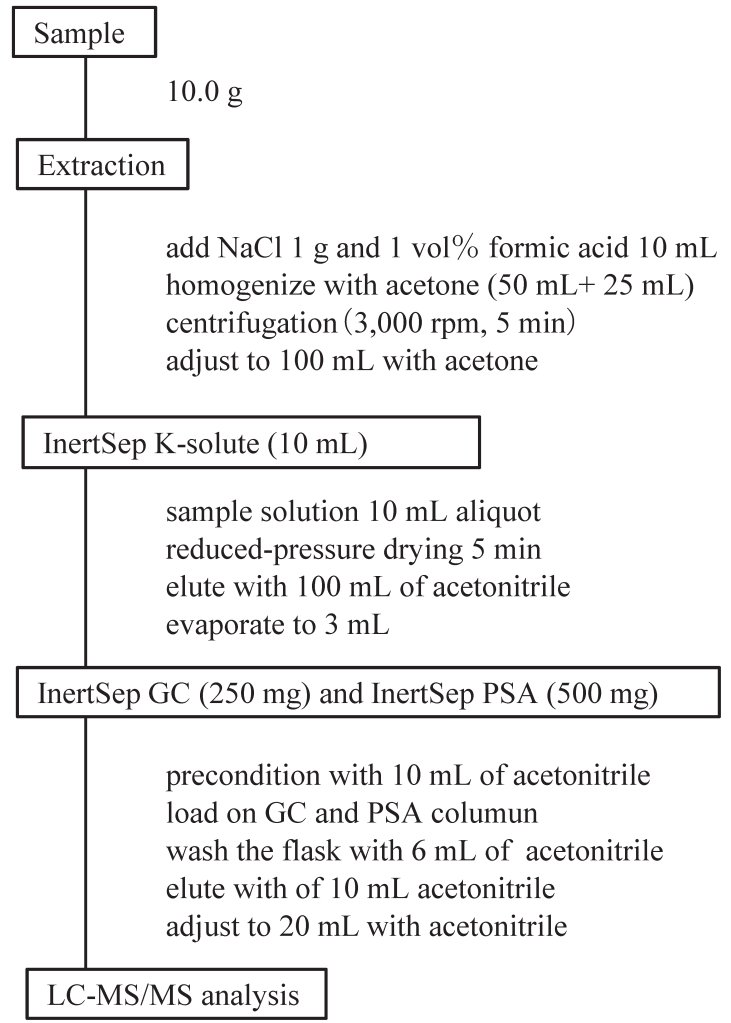

Scheme 1. Sample preparation method for analysis

ナイザー（10,000 rpm）で細砕した後，3,000回転で5分 間遠心し，その上澄液を分取した。残渣にアセトン $25 \mathrm{~mL}$ を加え, 1 回目と同様に細砕した後, 遠心した。 上澄液を 合わせ，アセトンを加えて $100 \mathrm{~mL} に$ 定容し, 試料抽出溶 液とした。

InertSep K-soluteカラムに試料抽出溶液を $10 \mathrm{~mL}$ 注入 し, 流下しないよう充填剤に浸潤させ, 吸引マニホールド を用いて，5分間吸引して大部分の溶媒を乾燥した．アセ トニトリル $100 \mathrm{~mL}$ を注入し, 全溶出液をナス型フラスコ に採り，減圧濃縮装置を用いて $40^{\circ} \mathrm{C}$ 以下で約 $3 \mathrm{~mL}$ まで濃 縮した。

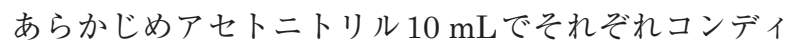
ショニングして打いた, InertSep GCカラムの下に InertSep PSAカラムを接続し, 約 $3 \mathrm{~mL}$ まで濃縮した溶 液を注入した後, 容器をアセトニトリル $6 \mathrm{~mL}$ で洗い, 洗 液をカラムに注入し，さらにアセトニトリル $10 \mathrm{~mL}$ を注 入し，全溶出液を合わせ，正確にアセトニトリルで $20 \mathrm{~mL}$ としたものを試験溶液とした（Scheme 1).

\section{6. 添加回収試験}

基準值濃度となるようフルオピコリド標準溶液を添加 し，30分間放置した後，本法に従って操作して，真度扔 よび併行精度を求めた.

\section{7. 試料マトリックスの測定への影響}

ブランク試料を5. 試験溶液の調製に従って調製し，こ の $2 \mathrm{~mL}$ 濃縮し, 標準溶液 $2 \mathrm{~mL}$ に溶解して添加回収試 験における回収率 $100 \%$ 相当濃度になるようにマトリック
ス標準溶液とした。マトリックス標準溶液の溶媒標準溶液 に対するピーク面積比（各 2 回測定の平均值）を求めて試 料マトリックスの測定への影響を検討した。

\section{結果および考察}

\section{1. 測定条件の検討}

\section{$1.1 \mathrm{MS}$ 条件の検討}

厚生労働省から通知されている「フルオピコリド試験法 (農産物)」は， LC-MS またはLC-MS/MSを用いてESIポ ジティブモードで測定捛よび確認する方法である，同様に ESIモードで測定する最適な条件を検討した。

ポジティブモードでは, フルオピコリドのプロトン付加 分子 $\left(\mathrm{m} / z 382.5[\mathrm{M}+\mathrm{H}]^{+}\right)$，ネガティブモードでは脱プ ロトン化分子 $\left(m / z 381.5[\mathrm{M}-\mathrm{H}]^{-}\right)$のモル質量 382 に 関するスペクトルが得られたが，ネガティブモードでの感 度はポジティブモードの $1 / 100$ 以下であったことから，測 定にはポジティブモードを用いることとした．フルオピコ リドのプロトン付加分子 $\left(m / z 382.5[\mathrm{M}+\mathrm{H}]^{+}\right)$をプリ カーサーイオンとした場合のプロダクトイオンのうち，イ オン強度の最も高い $m / z 172.9$ を定量用イオンに, 次にイ オン強度の高い $m / z 108.9$ を定性用イオンとした.

\section{$1.2 \mathrm{LC}$ 条件の検討}

分析カラムは, L-column2 ODS（内径 $2.1 \mathrm{~mm}$, 長さ $100 \mathrm{~mm}$, 粒子径 $5 \mu \mathrm{m}$ ：化学物質評価研究機構製), コア シェルカラムであるAccucore C18 (内径 $2.1 \mathrm{~mm}$, 長さ $100 \mathrm{~mm}$, 粒子径 $2.6 \mu \mathrm{m}$ ：サーモフィッシャーサイエン ティフィック社製）およびAscentis Express C18（内径 $2.1 \mathrm{~mm}$, 長さ $100 \mathrm{~mm}$, 粒子径 $5 \mu \mathrm{m}$ ：シグマアルドリッ チ製）を用いて検討を行ったところ，フルオピコリドの ピーク形状，分離および再現性について良好な結果が得ら れたので，L-column2 ODSを使用することにした.

移動相条件は,「フルオピコリド試験法 (農产物)」で は，アセトニトリルおよび $2 \mathrm{mmol} / \mathrm{L}$ 酶酸アンモニウム溶 液 $(1: 1)$ 混液でのアイソクラティック測定が用いられて いる. 分析カラム内の試料成分を迅速に流出させるため, また，後述する牛の肝臓での妨害ピークとの分離のため, グラジェント条件を検討した。 アセトニトリルおよび $2 \mathrm{mmol} / \mathrm{L}$ 酭酸アンモニウム溶液（1:9）から（9:1）ま での8分間のリニアグラジエントののち， $(9: 1)$ で1分間 保持する条件としたところ，フルオピコリドの保持時間は 6.1 分となり，試料成分も十分に分離して溶出させること ができた。

本条件を用いて添加回収試験の濃度範囲である 0.000125 0.0015 mg/Lで検量線を作成したところ，良好 な直線性（ $r=0.999 ）$ を示した。

\section{2. 試験溶液の調製}

\section{1 抽出}

抽出溶媒としてアセトンー $n$-ヘキサン混液（1:1および $1: 2)$ ，アセトンーアセトニトリル混液（1:1），酢酸エチ ル，酢酸エチルーアセトニトリル混液（1:1），ジエチル 
エーテルーアセトニトリル混液（1:1）について検討した. 水 $10 \mathrm{~mL}$ にルオピコリド標準溶液 $1 \mathrm{mg} / \mathrm{L}$ （アセトン溶 液） $0.1 \mathrm{~mL}$ を添加し, 塩化ナトリウム $1 \mathrm{~g}$ を加え, 各溶媒 50, $25 \mathrm{~mL}$ で1分間ホモジナイズ後, 毎分 3,000 回転で 5 分間遠心分離した。得られた上層（2層となった場合は有 機層）を合わせ $100 \mathrm{~mL}$ に定容後, $5 \mathrm{~mL}$ 分取し，アセト ニトリルに置換後, LC-MS/MSで測定した.アセトン, 酢酸エチルおよびジエチルエーテルで $99 \%$ 以上の回収結 果であった。 アセトンーn-ヘキサン混液（1:2）では $60 \%$ 未満と低かった。これは, フルオピコリドの $n$-ヘキサン への溶解性（溶解度： $0.20 \mathrm{~g} / \mathrm{L}\left(20^{\circ} \mathrm{C}\right)$ ) が十分ではない ためおよび水層に溶解したアセトンを十分に回収できな かったためと考えられる.

次に, 回収率の高かったアセトン, 酢酸エチルおよびジ エチルエーテルを用いて，牛の筋肉など 10 試料に，水 $10 \mathrm{~mL}$, 塩化ナトリウム $1 \mathrm{~g}$, 各溶媒 $50 \mathrm{~mL}$ を加え, 1 分 間ホモジナイズ後, 毎分 3,000 回転で 5 分間遠心分離し た。 その結果, アセトン以外では鶏の筋肉, 牛の肝蔵およ びさけなどエマルジョンを形成する試料があり, 上澄液を 分取することが困難であった。 そこでフルオピコリドの回 収率が高く, 抽出液を分取しやすいアセトンを抽出溶媒に 用いることにした.

次に回収率の向上のため塩化ナトリウムおよびギ酸の添 加を検討した.

牛の肝臓 $10 \mathrm{~g}$ にフルオピコリド標準溶液 $1 \mathrm{mg} / \mathrm{L} （ ア セ ~$ トン溶液） $0.1 \mathrm{~mL}$ を添加し, 30 分放置後, 塩化ナトリウ 厶 $1 \mathrm{~g}$ を加えたものと加えないものとで回収率を比較し た.アセトン抽出後, InertSepGCカラムおよびInertSep PSAカラムで精製を行った後, 試験溶液とした，塩 化ナトリウムを加えないと $79.6 \%$ ，加えた場合は $91.5 \%$ と塩析効果によると考えられる回収率の向上が見られた.

次に，ギ酸溶液を加えた場合の添加量を検討した．牛の 肝臓 $10 \mathrm{~g}$ にフルオピコリド標準溶液 $1 \mathrm{mg} / \mathrm{L}$ (アセトン溶 液） $0.1 \mathrm{~mL}$ を添加し，30分放置後，ギ酸（0.01〜 $1 \mathrm{vol} \%)$ $10 \mathrm{~mL}$ 加え, アセトン抽出後, GCカラムおよびPSAカ ラムで精製を行った後, 試験溶液とした。 ギ酸溶液を加え ない場合は $91 \%$ ，加えることにより $99 \%$ 以上と回収率の 向上が見られた。 また，ギ酸濃度が 1 vol\%ではクロマト グラム上でフルオピコリドに近接していたマトリックス ピークが消失した（Fig. 2)，ギ酸を加えることで，妨害 成分が分解または生成が抑制されたか，あるいはアセトン で抽出されにくくなったものと考えられた。 $1 \mathrm{vol} \%$ キ酸 溶液添加を採用することとした。

次に, $1 \mathrm{vol} \%$ ギ酸溶液を加えた場合の塩化ナトリウムの 添加量を検討した．牛の筋肉など 10 試料にフルオピコリド 標準溶液 $1 \mathrm{mg} / \mathrm{L}$ (アセトン溶液） $0.1 \mathrm{~mL}$ を添加し, 30 分放 置後, $1 \mathrm{vol} \%$ ギ酸溶液 $10 \mathrm{~mL}$, 塩化ナトリウム $0.5 \sim 3 \mathrm{~g}$ を 加えアセトン抽出後, GCおよびPSAカラムで精製を行っ た後, 試験溶液とした. 塩化ナトリウム $0.5 〜 3 \mathrm{~g}$ を加えた 場合と加えなかった場合の回収結果をTable 2 に示した.

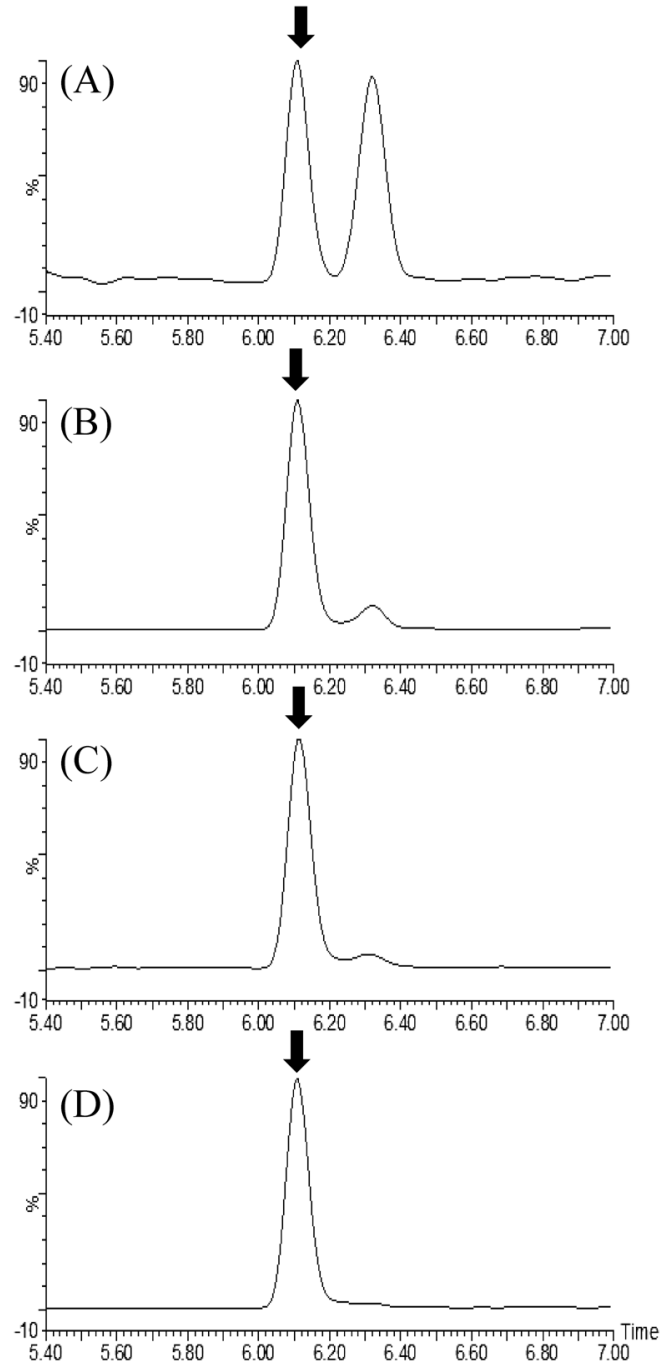

Fig. 2. SRM chromatograms of cattle liver fortified with $0.01 \mathrm{mg} / \mathrm{kg}$ fluopicolide, (A) without addition of formic acid, (B) addition of $0.1 \%$ formic acid, (C) addition of $0.5 \%$ formic acid, (D) addition of $1 \%$ formic acid

The scales of the $Y$-axis are the same in all chromatograms.

Table 2. Comparison of the recovery of fluopicolide from livestock products and seafood by the sodium chloride addition

\begin{tabular}{|c|c|c|c|c|c|}
\hline \multirow{3}{*}{ Sample } & \multicolumn{5}{|c|}{ Recovery $(\%)^{\text {a) }}$} \\
\hline & \multicolumn{5}{|c|}{ Sodium chloride (g) } \\
\hline & 0 & 0.5 & 1 & 2 & 3 \\
\hline Cattle, muscle & 84.3 & 91.5 & 98.3 & 98.0 & 98.2 \\
\hline Chicken & 90.1 & 97.5 & 97.7 & 97.5 & 101.0 \\
\hline Cattle, fat & 90.6 & 95.5 & 95.8 & 95.4 & 90.6 \\
\hline Cattle, liver & 89.1 & 92.2 & 97.3 & 96.8 & 93.1 \\
\hline Egg & 88.0 & 93.1 & 95.6 & 95.2 & 96.5 \\
\hline Milk & 95.7 & 95.5 & 100.6 & 97.5 & 100.3 \\
\hline Honey & 69.3 & 79.6 & 93.5 & 92.3 & 92.6 \\
\hline Eel & 97.1 & 100.0 & 100.3 & 99.7 & 99.0 \\
\hline Salmon & 98.8 & 98.2 & 99.8 & 99.1 & 98.1 \\
\hline Freshwater clam & 89.6 & 96.7 & 97.7 & 97.4 & 95.2 \\
\hline
\end{tabular}

\footnotetext{
a) Fortified level: $0.01 \mathrm{mg} / \mathrm{kg}, n=1$
} 
Table 3. Elution rate of fluopicolide from each mini-column

\begin{tabular}{|c|c|c|c|c|c|c|c|}
\hline \multirow{3}{*}{ Column } & \multicolumn{7}{|c|}{ Recovery $(\%)^{\text {a) }}$} \\
\hline & \multicolumn{6}{|c|}{ Acetonitrile (mL) } & \multirow{2}{*}{ Total } \\
\hline & $0-5$ & $5-10$ & $10-15$ & $15-20$ & $20-25$ & $25-30$ & \\
\hline InertSep GC (250 mg) + InertSep C18 (1 g) & 18.2 & 81.3 & 0.3 & 0.2 & 0 & 0 & 100.0 \\
\hline InertSep GC $(500 \mathrm{mg})+$ InertSep C18 $(1 \mathrm{~g})$ & 0.3 & 38.7 & 57.6 & 2.4 & 0.3 & 0.1 & 99.4 \\
\hline InertSep GC $(250 \mathrm{mg})+$ InertSep PSA $(500 \mathrm{mg})$ & 19.8 & 79.7 & 0.3 & 0.1 & 0 & 0 & 99.9 \\
\hline InertSep GC $(500 \mathrm{mg})+$ InertSep PSA $(500 \mathrm{mg})$ & 0.3 & 36.2 & 59.3 & 2.8 & 0.3 & 0.1 & 99.0 \\
\hline
\end{tabular}

a) One milliliter of standard solution $(0.01 \mathrm{mg} / \mathrm{L}$ in acetonitrile) was loaded on each column, and elute with acetonitrile, then was divided every $5 \mathrm{~mL} . n=1$

その結果，はちみつでは塩化ナトリウムを添加した場合 に，顕著な回収率の向上が見られた。 その他の試料におい ても回収率の向上が見られたが, 添加量 1 〜 g では回収

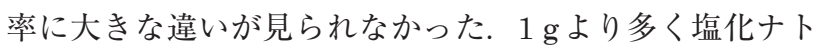
リウムを加えた場合, ホモジナイズ時に試料の分散が均一 に行われにくく，シャフトに付着しやすい傾向が見られた ことから, 回収率が高く, ホモジナイズ時に均一になる $1 \mathrm{~g}$ を用いることとした。

\section{2 脱脂法の検討}

操作の簡便性向上およびエマルジョンによる回収率低下 を考慮し, 多孔性ケイソウ土カラムクロマトグラフィーに よる脱脂5) 8) を検討した.

InertSep K-soluteカラムにフルオピコリド標準溶液 $0.01 \mathrm{mg} / \mathrm{L}$ (アセトン溶液) $1 \mathrm{~mL}$ およびアセトン $9 \mathrm{~mL}$ 負荷し, 5 分間吸引乾燥後, アセトニトリル $30 \mathrm{~mL} 1$ 分画 および $10 \mathrm{~mL} 10$ 分画で溶出し, 各溶出液にアセトニトリ ルを加え，10 mLに定容後LC-MS/MSで測定した。アセ トニトリル溶出量 $100 \mathrm{~mL}$ で $96 \%$ 以上の回収率が得られた ことから，アセトニトリル $100 \mathrm{~mL}$ で溶出することとし た. 牛の脂肪をこの条件で脱脂したところ, 目視では濃縮 後に残留物が確認されず，良好な脱脂効果が得られた。

\section{3 精製法の検討}

「フルオピコリド試験法 (農産物)」では, GCおよびオ クタデシルシリル化シリカゲルミニカラム（C18）を用い て精製を行っている。同様にGCおよびC18カラムについ て，また脂肪酸等の除去に用いられるPSAカラムについ て検討を行った.

それぞれ単独で精製した場合, C18およびPSAカラムで は試料溶液の色素除去が不十分であり, また, GCカラムに おいても, 溶媒標準溶液とマトリックス添加標準溶液の ピーク面積比に $30 \%$ 程度の差異が認められた.これはLCMS/MS 測定時のイオン化抑制によるものと考えられた。

そこで， $\mathrm{GC}$ および $\mathrm{C} 18$ カムムの組合せと， $\mathrm{GC}$ および PSAカラムの組合せについて検討した.

カラムをアセトニトリル $10 \mathrm{~mL}$ でコンディショニング した後, GCカラムを上にしてカラムを連結し, フルオピ コリド標準溶液 $0.01 \mathrm{mg} / \mathrm{L}$ (アセトニトリル溶液) $1 \mathrm{~mL}$ 負荷し, アセトニトリルで溶出したときの溶出状況を Table 3 に示した。 いずれの組合せにおいても $99 \%$ 以上の
Table 4. Recovery of fluopicolide from livestock products and seafood

\begin{tabular}{|c|c|c|c|c|}
\hline \multirow[t]{2}{*}{ Sample } & MRL & $\begin{array}{c}\text { Fortified } \\
\text { level }\end{array}$ & Recovery $^{\text {a) }}$ & $\mathrm{RSD}^{\mathrm{b})}$ \\
\hline & $(\mathrm{mg} / \mathrm{kg})$ & $(\mathrm{mg} / \mathrm{kg})$ & $(\%)$ & $(\%)$ \\
\hline Cattle, muscle & 0.01 & 0.01 & 100.0 & 3.1 \\
\hline Chicken & 0.01 & 0.01 & 98.5 & 5.4 \\
\hline Cattle, fat & 0.01 & 0.01 & 97.8 & 3.7 \\
\hline Cattle, liver & 0.01 & 0.01 & 97.8 & 2.7 \\
\hline Egg & 0.01 & 0.01 & 98.5 & 3.4 \\
\hline Milk & 0.02 & 0.02 & 100.4 & 2.8 \\
\hline Honey & 一 $^{c}$ & 0.01 & 96.7 & 6.2 \\
\hline Eel & $-^{c)}$ & 0.01 & 97.7 & 3.1 \\
\hline Salmon & - $^{c}$ & 0.01 & 98.7 & 2.3 \\
\hline Freshwater clam & $-^{c)}$ & 0.01 & 98.6 & 3.9 \\
\hline
\end{tabular}

回収が得られた。

次に, 牛の筋肉など 10 試料の抽出した溶液を GC カラム $250 \mathrm{mg}$ と連結した場合はアセトニトリル $20 \mathrm{~mL}$ で, GCカ ラム $500 \mathrm{mg}$ と連結した場合はアセトニトリル $30 \mathrm{~mL}$ で溶 出した．減圧濃縮後，残留物の重量を測定したところ，GC およびC18カラムの組合せでは 0.001 未満〜 $0.015 \mathrm{~g}, \mathrm{GC}$ およびPSAカラムの組合せでは $0.001 \mathrm{~g}$ 未満であった。 GC およびPSAカラムを組合せたほうが試料マトリックス の影響を受けにくいと考えられた。そこで，GCカラム $500 \mathrm{mg}$ との組合せよりも溶出液量が少なく, また, フル オピコリドの回収率が $99.9 \%$ と良い GC カラム $250 \mathrm{mg}$ お よびPSAカラム $500 \mathrm{mg}$ の組合せを採用した.

\section{3. 添加回収試験}

フルオピコリドが検出されないことを確認した 10 種類 の試料 $10 \mathrm{~g}$ に, 残留基準值濃度になるよう添加し, 30 分 間放置した後, 本法に従って操作して5併行の回収率を求 めた。その結果, Table 4 に示したように真度は96〜 $100 \%$ ，併行精度は $2.3 \sim 6.2 \%$ と良好であった．検討した いずれの試料においても, フルオピコリドの定量を妨害す るピークは認められず，選択性も良好であった（Fig. 3).

\section{4. 試料マトリックスの測定への影響}

0.01 および $0.02 \mathrm{mg} / \mathrm{L} の$ 溶媒標準溶液と同濃度になるよ 

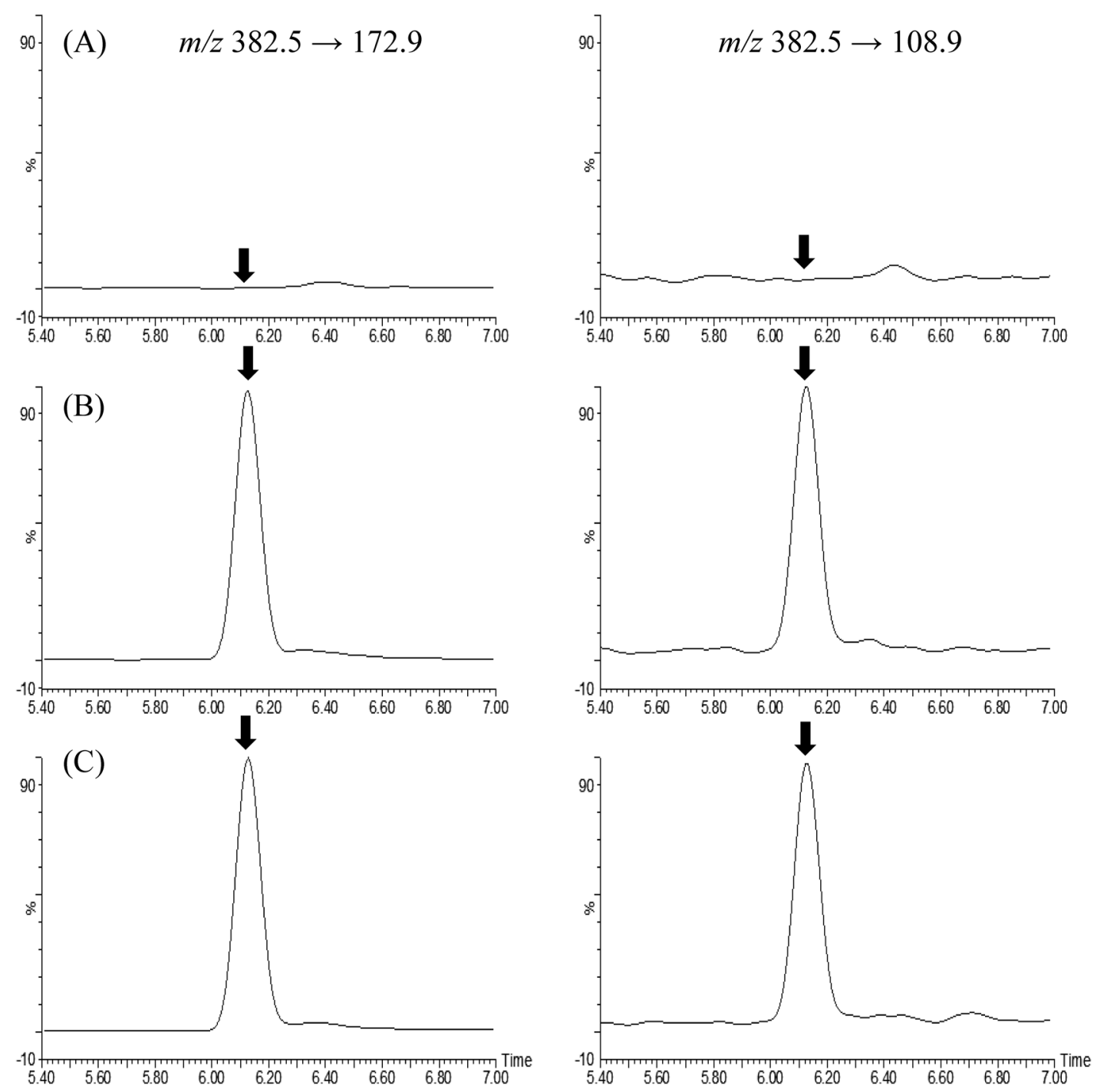

Fig. 3. SRM chromatograms of (A) cattle liver blank, (B) cattle liver fortified with $0.01 \mathrm{mg} / \mathrm{kg}$ fluopicolide, (C) standard solution of fluopicolide $(0.0005 \mathrm{mg} / \mathrm{L})$

The scales of the $Y$-axis are the same in all chromatgrams.

うにマトリックス添加標準溶液を調製し，マトリックス添 加標準溶液の溶媒標準溶液に対するピーク面積比を求め た. 面積比は $0.93 \sim 1.02$ といずれの試料においても，顕 著なマトリックスの測定への影響は認められなかった。

$0.001 \mathrm{ppm}$ 添加相当になるように調製したマトリックス 添加標準溶液での $S / N$ 比を求めたところ, 平均值は 22 31 であり, すべての食品で $S / N \geqq 10$ を満たし，検討した いずれの畜水産物においれも $0.01 \mathrm{mg} / \mathrm{kg}$ を設定可能で あった。

\section{ま と め}

LC-MS/MSを用いた畜水産物中のフルオピコリド試験 法を検討した，試料に塩化ナトリウムを加え，ギ酸酸性下 アセトンで抽出し, ケイソウ土カラムで脱脂後, GCおよ びPSAカラムで精製して，LC-MS/MSで測定した１0 種 類の畜水産物 (牛の筋肉, 鶏の筋肉, 牛の脂肪, 牛の肝 臓, 鶏卵, 牛乳, はちみつ, うなぎ, さけおよびしじみ)
を対象に基準值濃度で添加回収試験を行った結果，真度は 96〜100\%，併行精度は 2.3〜 6.2\%であり，良好な結果が 得られた，定量限界は，検討したいずれの畜水産物におい ても $0.01 \mathrm{mg} / \mathrm{kg}$ を設定できた。

\section{謝辞}

本研究は, 厚生労働省医薬食品局食品安全部（現医薬・ 生活衛生局生活衛生・食品安全部）「平成 26 年度食品に残 留する農薬等の成分である物質の試験法開発事業」により 実施したものである。関係各位に深謝いたします。

\section{文献}

1）沢田勝鏡. 近年開発されたべと・疫病防除薬剂の各種特性 と効果的な使用方法一新規化合物フルオピコリドー． EBC 研究会誌, 5, 49-55 (2009).

2) Akiyama, Y., Matsuoka, T. Application of Multi-residue Analytical Method for 12 Pesticides Added to the 
Positive List, Bulletin of Hyogo Prefectural Institute of Public Health and Consumer Sciences. Public Health Science Research Center, 1, 38-42 (2010).

3) Paramasivam, M., Chandrasekaran S. Determination of fluopicolide in grapes and soil using an easy sample preparation method and gas chromatography-mass spectrometry. Toxicological and Environmental Chemistry, 95, 1470-1476 (2013).

4）残留農薬等公示分析法検討会. 通知法解説 食品中の残留 農薬・動物用医薬品等試験法 37一食品に残留する農薬, 飼 料添加物又は動物用医薬品の成分である物質の試験法一 （104）フルオピコリド (農産物). 食品衛生研究, 5, 5558 (2009).

5) Iijima, K., Saka, M., Odanaka, Y., Matano, O. Multiresidue analytical method of pesticides by GC-MS:
Application of macroporous diatomaceous earth column and silica gel cartridge. J. Pestic. Sci., 22, 17-26 (1997).

6) Ueno, E. Application of macroporous diatomaceous earth column chromatography for pesticide residue analysis in foods. J. Pestic. Sci., 35, 74-78 (2010).

7) Kobayashi, M., Otsuka, K., Tamura, Y., Tomizawa, S., Kamijo, K., Iwakoshi, K., Sato, C., Nagayama, Y., Takano, I. Study on rapid analysis method of pesticide con-tamination in processed foods by GC-MS and GCFPD. Shokuhin Eiseigaku Zasshi (Food Hyg. Saf. Sci.), 52, 182-236 (2011).

8) Ueno, E., Ohno, H., Watanabe, M., Oshima, H., Mikami, E., Nemoto, S., Mstsuda, R. Analysis of spinosad in animal and fishery products by LC-MS. Shokuhin Eiseigaku Zasshi (Food Hyg. Saf. Sci.), 52, 330-335 (2011). 